\title{
KOMPOSISI KIMIA DAN NILAI SENSORIK STIK IKAN TUNA (Thunnus sp.) DENGAN PENAMBAHAN TEPUNG BUAH MANGROVE (Bruguiera gymnorrhiza)
}

Chemical Composition and Sensoric Value of Tuna Fish Sticks (Thunnus sp.) with Addition of Mangrove Flour (Bruguiera gymnorrhiza)

\author{
Dina $^{1^{*}}$, Asnani ${ }^{1}$, Sri Rejeki ${ }^{2}$ \\ 1Jurusan Teknologi Hasil Perikanan, Fakultas Perikanan dan Ilmu Kelautan Universitas Halu Oleo, Kendari, \\ Sulawesi Tenggara, Indonesia \\ 2Jurusan IImu dan Teknologi Pangan, Fakultas Pertanian Universitas Halu Oleo, Kendari, Sulawesi Tenggara, \\ Indonesia \\ *Email korespondensi: dinalaalifu@gmail.com (Telp: +6285280328521) \\ Diterima: 8 Oktober/ Disetujui 20 Desember 2019
}

Cara sitasi: Dina, Asnani, Rejeki S. 2020. Komposisi kimia dan nilai sensorik stik ikan tuna (Thunnus sp.) dengan penambahan tepung buah mangrove (Bruguiera gymnorrhiza). Jurnal Fish Protech. 3(1):17-24.

\section{ABSTRACT}

This study aims to determine the effect of the addition of mangrove flour to sensory properties and water content and protein content of tuna sticks. This study used a Completely Randomized Design (CRD) with a combination of the use of fish meat and mangrove flour (from total stick ingredients) in a row: 50: 0\% $\left(I_{50} M_{0}\right), 45: 5 \%\left(I_{45} M_{5}\right), 40: 10 \%\left(I_{40} M_{10}\right)$, and $35: 15 \%\left(I_{35} M_{15}\right)$. The results showed the addition of mangrove flour with different concentrations significantly affected the sensory properties of color, aroma, texture, appearance and water content and protein content of tuna sticks but did not significantly affect the taste sensory attributes. The sensory attributes of color, aroma, texture, appearance, water content and protein content obtained the highest average values were $7.08,6.07,7.03,6.6,9.52$ respectivelyand 14.58 while the sensory attributes of taste obtained the highest average values around 6.71. The combination of the use of fish meat and mangrove flour on the color and aroma sensory attributes of the $I_{35} M_{15}$ treatment is preferred while the sensory attributes of the texture, taste and appearance of $\mathrm{I}_{40} \mathrm{M}_{10}$ are preferred.

Keywords: Bruguiera gymnorrhiza, mangroves, sensoric, Thunnus sp., tuna sticks.

\begin{abstract}
ABSTRAK
Penelitian ini bertujuan untuk mengetahui pengaruh penambahan tepung mangrove terhadap sifat sensorik dan komposisi kimia stik ikan. Penelitian ini menggunakan Rancangan Acak Lengkap (RAL) dengan kombinasi penggunaan daging ikan dan tepung mangrove (dari total bahan stik) berturut-turut:50:0 \% $\left(\mathrm{I}_{50} \mathrm{M}_{0}\right), 45: 5 \%\left(\mathrm{l}_{45} \mathrm{M}_{5}\right), 40: 10 \%\left(\mathrm{l}_{40} \mathrm{M}_{10}\right)$, dan $35: 15 \%\left({ }_{35} \mathrm{M}_{15}\right)$. Hasil penelitian menunjukkan penambahan tepung mangrove dengan konsentrasi yang berbeda berpengaruh nyata terhadap sifat sensorik warna, aroma, tekstur, kenampakan dan kadar air serta kadar protein stik tuna namun tidak berpengaruh nyata pada atribut sensorik rasa. Nilai rerata tertinggi pada atribut sensorik warna, aroma, tekstur, kenampakan, kadar air dan kadar protein berturut-turut yaitu 7.08, 6.07, 7.03, 6.6, 9.52 dan 14.58 sedangkan pada atribut sensorik rasa diperoleh nilai rerata tertinggi sekitar 6,71. Kombinasi penggunaan daging ikan dan tepung mangrove pada atribut sensorik warna dan aroma perlakuan ${ }_{35} \mathrm{M}_{15}$ lebih disukai sedangkan pada atribut sensorik tekstur, rasa dan kenampakan ${ }_{40} \mathrm{M}_{10}$ lebih disukai dibandingkan pada perlakuan $\mathrm{I}_{35} \mathrm{M}_{15}$.
\end{abstract}

Kata kunci: Bruguiera gymnorrhiz, mangrove, sensorik, stik tuna, Thunnus sp.

\section{PENDAHULUAN}

Indonesia merupakan negara dengan potensi tuna tertinggi di dunia. Data resmi FAO mencatat tahun 2014, Indonesia berhasil memasok lebih dari $16 \%$ total produksi dunia yang mencapai lebih dari 1,1 
juta ton/tahun (Ditjen PT 2015). Komoditas ikan unggulan menurut laporan PPS Kendari (2016), adalah ikan tuna, layang/kembung, dan cakalang. Hasil tangkapan ikan tuna diperoleh dari perairan Selat Makassar, Selat Bone, dan selat Laut Banda (Statistik PPS Kendari, 2016)

Tuna merupakan salah satu jenis ikan yang mempunyai nilai ekonomis yang tinggi. Menurut Stanby (1982), kelompok ini termasuk kelas $D$, dengan kandungan lemak yang rendah dan protein sangat tinggi $(>20 \%)$. Bagian daging putih ikan tuna kurang lebih $98 \%$ dan daging merah (gelap) $2 \%$. Daging ikan tuna menjadi sumber DHA yang sangat penting bagi kesehatan. Ikan tuna pada umumnya dimanfaatkan untuk produksi pengalengan dan pembekuan. Tuna biasanya di jual dalam bentuk produk beku, utuh maupun dalam bentuk loin beku sedangkan untuk bagian kepala, sirip dan tulang hanya dibuat dalam bentuk tepung ikan (Wardani, 2012). Selain pengolahan dalam bentuk beku, ikan tuna juga dapat diolah dalam bentuk produk kering seperti stik ikan. Diversifikasi produk perikanan dilakukan agar masyarakat tidak cepat bosan dan dapat meningkatkan minat masyarakat terhadap pentingnya mengkonsumsi ikan.

Stik ikan adalah salah satu makanan ringan (makanan camilan) berbahan dasar ikan yang digoreng dengan rasa asin atau gurih, teksturnya keras dan renyah, berbentuk batang panjang dan mengembang dengan warna kuning kecoklatan. Untuk memperbaiki tekstur stik ikan supaya menjadi elastis dan tidak mudah hancur diperlukan adanya penambahan bahan pengisi yaitu tepung (Aryani, 2016).

Tepung mangrove merupakan salah jenis tepung yang dapat diaplikasikan dalam pembuatan stik ikan tuna. Spesies Bruguiera gymnorrhiza dikenal dengan nama tancang atau lindur berbuah sepanjang tahun dengan pohon yang kokoh dan tingginya mencapai $\pm 35 \mathrm{~m}$. Buah lindur secara tradisional telah dimanfaatkan oleh masyarakat suku Biak sebagai sumber karbohidrat sebagai pengganti tepung sagu (Wanma, 2007). Buah lindur juga digunakan sebagai pengganti beras dan jagung ketika krisis pangan di
Flores, Sumba, Sabu, dan Alor (Haryono, 2004). Nilai kalori buah lindur sebesar 371 kalori per 100 gram lebih tinggi dibandingkan berast dan jagung yaitu sebesar 360 kalori per 100 gram dan 307 kalori per 100 gram (Fortuna, 2005).

Bruguiera gymnorrhiza merupakan salah satu jenis mangrove yang dapat dimanfaatkan sebagai sumber pangan baru (Bayu, 2009). Tepung ini memiliki kandungan karbohidrat dan energi yang lebih tinggi dari beras, jagung, dan singkong. Kandungan protein buah mangrove juga lebih besar dari tepung singkong. Tepung Bruguiera gymnorrhiza juga memiliki kandungan vitamin $\mathrm{C}$, serat baik dikonsumsi bagi penderita autis yang tidak dapat mengkonsumsi olahan dari tepung terigu (Perkasa, 2013). Tepung buah mangrove telah dimanfaatkan dalam pembuatan kue putri salju, dodol, nuget dan kerupuk.

Berdasarkan penjelasan diatas maka perlu dilakukan penelitian tentang pembuatan stik ikan tuna dengan penambahan tepung mangrove untuk mengetahui pengaruh uji organoleptik dan kimia pada stik ikan tuna.

\section{Alat dan Bahan}

\section{METODE PENELITIAN}

Alat yang digunakan dalam penelitian ini ada 2 macam yaitu alat untuk pengolahan dan alat untuk analisis. Alat pengolahan meliputi baskom, pisau, talenan, sendok, blender, cetakan, panci, kompor, dan wajan. Alat untuk analisis kimia meliputikrus, desikator, oven, neraca analitik, tanur pengabuan, labu kjeldahl, destruktor, destilator, tabung destilasi, buret, soxhlet, kertas saring whatman, oven.

Bahan yang digunakan dalam penelitian ini adalah ikan tuna yang diperoleh di TPI Sodoha, Kendari, tepung terigu (segitiga biru), telur, tepung mangrove, merica (ladaku), margarine (blueband), garam, dan minyak goreng (bimoli) Bahan untuk analisis kimia adalah $\mathrm{H} 2 \mathrm{SO} 4$ pekat, $\mathrm{K} 2 \mathrm{SO} 4, \mathrm{HgO}$, $\mathrm{NaOH} 50 \%$, K2S 4\%, indikator metil merah, lempeng $\mathrm{Zn}, \mathrm{HCl} 0,1 \mathrm{~N}$, larutan standar $0,1 \mathrm{~N}$, aquades, benzene, $\mathrm{HNO}$, dan $\mathrm{HClO} 4$. 


\section{Rancangan Penelitian}

Penelitian ini menggunakan Rancangan Acak Lengkap ( $R A L$ ) untuk menguji pengaruh penambahan tepung buah mangrove terhadap uji organoleptik dan uji kimia pada stik ikan tuna yang terdiri dari 4 perlakuan dengan perbandingan daging ikan tuna dan tepung mangrove masing-masing yaitu $\mathrm{I}_{50} \mathrm{M}_{0}(50 \%$ daging ikan :0\% tepung mangrove), ${ }_{45} \mathrm{M}_{5}$ (45\% daging ikan :5\% tepung mangrove), $\left.\right|_{40} \mathrm{M}_{10}$ (40\% daging ikan $: 10 \%$ tepung mangrove), ${ }_{35} \mathrm{M} 1_{5}$ (35\% daging ikan $: 15 \%$ tepung mangrove). Masing-masing perlakuan di ulang sebanyak 3 kali, sehingga diperoleh jumlah satuan percobaan sebanyak 12 unit percobaan.

\section{Prosedur Penelitian}

\section{a. Pembuatan Tepung Buah Mangrove}

Bahan baku yang dipilih untuk pembuatan tepung antara lain tidak cacat fisik dan tidak busuk. Buahlindur yang telah dipilih kemudian dicuci. Direbus selama 30 menit dan dilanjutkan dengan proses pengupasan. Setelah perendaman buah mangrove kemudian dicacah dan ditiriskan selama \pm 10 menit lalu dijemur dibawah sinar matahari \pm 3 hari. Setelah pengeringan kemudian dilanjutkan dengan penggilingan dan diayak dengan menggunakan ukuran ayakan 100 mesh (Dimodifikasi dari salim, 2011).

\section{b. Parameter Uji \\ 1. Uji sensori (BSN, 2006)}

Untuk menentukan stik ikan tuna yang paling disukai oleh panelis dari setiap perlakuan, dilakukan penilaian sensorik terhadap produk stik ikan tuna yang meliputi aroma, warna, tekstur, rasa, dan kenampakan dengan menggunakan skala sensori. Pengujian ini menggunakan 25 orang panelis dan berdasarkan pada SNI 01-2346-2006.

\section{Uji kimia}

Analisis uji kimia pada stik ikan tuna meliputi kadar air (AOAC, 2005), dan kadar protein (AOAC, 2005).

\section{A. Kadar Air (AOAC 2005)}

Analisis kadar air dilakukan menggunakan metode oven. Prinsipnya adalah menguapkan air yang ada didalam sampel dengan cara pemanasan. Tahap pertama yang dilakukan untuk menganalisis kadar air adalah mengeringkan cawan porselin dalam oven pada suhu $105^{\circ} \mathrm{C}$ selama 1 jam. Cawan tersebut diletakkan didalam desikator (kurang lebih 15 menit) dan dibiarkan sampai dingin kemudian ditimbang. Cawan tersebut ditimbang kembali hingga beratnya konstan. Sebanyak 5 gram contoh dimasukkan kedalam cawan, kemudian dikeringkan dalam oven pada suhu $105^{\circ} \mathrm{C}$ selama 5 jam, kemudian cawan dimasukkan ke dalam desikator sampai dingin dan selanjutnya ditimbang kembali.

\section{B. Kadar Protein (AOAC 2005)}

Analisis kadar protein dilakukan dengan menggunakan metode Kjeldahl. Metode ini terdiri dari tiga tahap, yaitu tahap destruksi, destilasi, dan titrasi. Sampelyang akan dianalisis ditimbang sebanyak 0.25 gram kemudian dimasukkan kedalam labu Kjeldahl $100 \mathrm{ml}$ dan ditambahkan 0.25 gram selenium mix dan $3 \mathrm{ml} \mathrm{H}_{2} \mathrm{SO}_{4}$ pekat. Sampel didestruksi selama 1-2 jam hingga jernih kehijau hijauan lalu didinginkan. Sampel kemudian diencerkan hingga tanda tera dengan menggunakan aquades. Pindahkan larutan sebanyak $5 \mathrm{ml}$ kedalam alat penyuling lalu

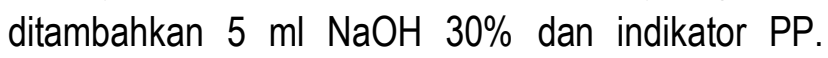
Penyulingan dilakukan selama 10 menit dengan penampung $10 \mathrm{ml}$ larutan asam borat $2 \%$ yang dicampur dengan indikator PP. Tahap terakhir titrasi dilakukan dengan menggunakan larutan $\mathrm{HCl} 0.01 \mathrm{~N}$.

\section{Analisis Data}

Data hasil penelitian organoleptik dianalisis menggunakan sidik ragam ANOVA (Analisis of Varians), jika terdapat perbedaan yang sangat signifikan maka akan dilakukan uji DMRT(Duncan multiple range test) dengan tingkat kepercayaan 95\% menggunakan software SPSS versi 22. 


\section{HASIL DAN PEMBAHASAN}

Hasil penilaian pada atribut sensorik warna, aroma, tekstur dan kenampakan menunjukkan bahwa penambahan tepung mangrove pada stik ikan berpengaruh sangat nyata terhadap rerata sifat

\section{Sifat sensorik}

sensorik namun tidak berpengaruh nyata terhadap sifat sensorik rasa dan hasil uji DMRT0,05 disajikan pada Tabel 1.

Tabel 1. Rerata hasil penelitian uji sensorik stik ikan

\begin{tabular}{lccccc}
\hline \multirow{2}{*}{ Perlakuan } & \multicolumn{5}{c}{ Uji Sensorik } \\
\cline { 2 - 6 } & Warna $\pm S D$ & Aroma $\pm S D$ & Tektur $\pm S D$ & Rasa $\pm S D$ & kenampakan $\pm S D$ \\
\hline $\mathrm{I}_{50} \mathrm{M}_{0}$ & $3,59 \pm 0,62^{\mathrm{a}}$ & $5,03 \pm 0,28^{\mathrm{a}}$ & $6,39 \pm 0,30^{\mathrm{a}}$ & $6,33 \pm 0,71^{\mathrm{a}}$ & $6,04 \pm 0,71^{\mathrm{a}}$ \\
$\mathrm{I}_{45} \mathrm{M}_{5}$ & $5,45 \pm 0,13^{\mathrm{b}}$ & $5,56 \pm 0,29^{\mathrm{b}}$ & $6,57 \pm 0,38^{\mathrm{b}}$ & $6,36 \pm 0,24^{\mathrm{a}}$ & $6,47 \pm 0,24^{\mathrm{b}}$ \\
$\mathrm{I}_{40} \mathrm{M}_{10}$ & $6,13 \pm 0,31^{\mathrm{b}}$ & $5,56 \pm 0,21^{\mathrm{b}}$ & $7,03 \pm 0,12^{\mathrm{b}}$ & $6,49 \pm 0,12^{\mathrm{a}}$ & $6,6 \pm 0,12^{\mathrm{b}}$ \\
$\mathrm{I}_{35} \mathrm{M}_{15}$ & $7,08 \pm 0,29^{\mathrm{c}}$ & $6,07 \pm 0,05^{\mathrm{c}}$ & $6,79 \pm 0,12^{\mathrm{b}}$ & $6,71 \pm 0,2^{\mathrm{a}}$ & $6,41 \pm 0,2^{\mathrm{b}}$
\end{tabular}

Ket: angka yang diikiuti dengan notasi huruf yang berbeda menunjukkan nilai yang berbeda nyata pada tingkat kepercayaan $95 \%(\alpha<0,05)$

\section{a. Warna}

Hasil uji ANOVA (Tabel 1) menunjukkan bahwa warna stik ikan yang ditambahkan dengan tepung buah mangrove menunjukkan hasil yang berbeda nyata $(\alpha<0,05)$. Hasil uji lanjut DMRT menunjukkan nilai warna stik ikan dengan penambahan tepung buah mangrove $15 \% \quad\left(I_{35} \mathrm{M}_{15}\right)$ berbeda nyata dengan penambahan tepung mangrove $10 \%\left(\mathrm{I}_{40} \mathrm{M}_{10}\right)$ dan $0 \%$ $\left(\mathrm{I}_{50} \mathrm{M}_{0}\right)$ sedangkan pada penambahan konsentrasi $5 \%$ $\left(\mathrm{I}_{50} \mathrm{M}_{0}\right)$ dan $10 \%\left(\mathrm{I}_{40} \mathrm{M}_{10}\right)$ tidak berpengaruh nyata.

Berdasarkan rerata nilai stik ikan berkisar antara 3,59 hingga7,08. Nilai sifat sensorik warna pada stik ikan tuna dengan penambahan tepung mangrove diperoleh nilai tertinggi pada perlakuan $\mathrm{I}_{35} \mathrm{M}_{15}$ dengan konsentrasi tepung mangrove 15\% dengan kriteria coklat tua. Hal ini disebabkan karena senyawa tanin yang terdapat dalam tepung mangrove sehingga mengahasilkan warna yang gelap (coklat tua). Serupa dengan penelitian yang dilakukan oleh Rhomadon (2015), warna pada tepung B. gymnorrhiza akan semakin putih jika dilakukan perendaman lebih lama karena kandungan tanin yang terdapat pada buah mangrove $B$. gymnorrhiza akan larut bersama dengan air. Kandungan tanin pada buah $B$ gymnorrhiza menyebabkan warna menjadi coklat. Pendapat lain tentang proses terjadinya pencoklatan pada stik yaitu akibat terjadi reaksi maillard pada saat proses penggorengan. Hal ini sesuai dengan Penelitian Winarno (2004) yang menyatakan bahwa produk stik yang memiliki warna coklat disebabkan adanya reaksi Maillard (reaksi-reaksi antara karbohidrat, khususnya gula pereduksi dengan gugus amina primer yang terdapat pada bahan sehingga menghasilkan bahan berwarna coklat).

\section{b. Aroma}

Hasil uji ANOVA (Tabel 1) menunjukkan bahwa aroma stik ikan yang ditambahkan dengan tepung buah mangrove menunjukkan hasil yang berbeda nyata $(\alpha<0,05)$. Hasil uji lanjut DMRTmenunjukkan nilai aroma stik ikan dengan penambahan tepung buah mangrove $15 \%$ berbeda nyata dengan penambahan tepung mangrove $0 \%$ dan $10 \%$ namun tidak berbeda nyata antara penambahan tepung mangrove dengan konsentrasi $5 \%$ dan $10 \%$.

Sifat sensorik aroma menunjukkan bahwa semakin banyak jumlah konsentrasi tepung mangrove yang ditambahkan maka aroma ikan pada stik ikan akan semakin berkurang. Hasil penelitian sifat 
sensorik aroma diperoleh nilai rerata tertinggi pada perlakuan ${ }_{35} \mathrm{M}_{15}$ sekitar 6,07 dengan penambahan tepung mangrove $(15 \%)$ dan nilai terendah terdapat pada perlakuan $\mathrm{I}_{50} \mathrm{M}_{0}$ yaitu sekitar 5,03 dengan konsentrasi tepung mangrove $0 \%$ (Tabel 1). Hal ini dikerenakan semakin banyak jumlah tepung mangrove yang ditambahkan dalam stik ikan maka aroma ikan akan semakin berkurang. Penelitian ini sesuai dengan pendapat Liviawaty (2018), yang menyatakan bahwa tepung mangrove memiliki aroma khas tepung mangrove sehingga semakin banyak penambahan tepung mangrove yang digunakan maka aroma tepung mangrove dapat menutupi aroma khas bakso lele. Menurut Perkasa (2013), aroma yang dihasilkan oleh biskuit lindur berasal dari bahan-bahan yang digunakan dalam adonan biscuit seperti margarin, gula, telur, vanili. Selain aroma yang dihasilkan dari bahan-bahan tersebut, aroma yang dihasilkan oleh tepung lindur juga dapat tercium pada biskuit.

\section{c. Tekstur}

Hasil uji ANOVA (Tabel 1) menunjukkan bahwa tekstur stik ikan yang ditambahkan dengan tepung buah mangrove menunjukkan hasil yang berbeda nyata $(\alpha<0,05)$. Hasil uji lanjut DMRT menunjukkan nilai tekstur stik ikan dengan penambahan tepung buah mangrove $15 \%$ berbeda nyata dengan penambahan tepung mangrove $0 \%$. Hasil penilaian pada atribut sensorik tekstur stik ikan dengan penambahan tepung mangrove menunjukkan bahwa penambahan tepung mangrove $10 \% \quad\left(\mathrm{I}_{40} \mathrm{M}_{10}\right)$ berpengaruh sangat nyata terhadap rerata sifat sensorik pada atribut tekstur dan hasil uji DMRT disajikan pada Tabel 1. Hasil analisis statistik nilai stik ikan berkisar antara 6,39 hingga 7,03. Rerata nilai sensorik pada atribut tekstur stik ikan diperoleh nilai tertinggi pada perlakuan $\mathrm{I}_{40} \mathrm{M}_{10}$ yaitu 7,03 dengan konsentrasi tepung mangrove $10 \%$ (Tabel 1). Tingkat kerenyahan stik ikan dipengaruhi kadar amilosa dalam tepung mangrove. Semakin tinggi kadar amilosa dalam stik ikan maka tingkat kerenyahannya akan semakin meningkat. Hal ini sesuai dengan pendapat Laga (2006), yang menyatakan bahwa daging buah mangrove menyebabkan meningkatnya jumlah amilosa sebagai akibat terjadinya pemutusan rantai cabang amilopektin ikan a 1-6 glikosida sehingga meningkatkan jumlah rantai lurus amilosa. Artinya dengan penambahan tepung mangrove yang terlalu banyak akan mempengaruhi tekstur dari stik ikan. Menurut Seknum (2012), yang menunjukkan hasil pengujian amilopektin pada tepung mangrove $\mathrm{B}$. gymnorrhiza adalah $26,17 \%$.

\section{d. Rasa}

Hasil uji ANOVA (Tabel 1) menunjukkan bahwa pada atribut rasa stik ikan yang ditambahkan dengan tepung buah mangrove menunjukkan hasil yang tidak berbeda nyata $(a<0,05)$. Berdasarkan hasil analisis keragaman menunjukkan bahwa baik pada perlakuan $\mathrm{I}_{50} \mathrm{M}_{0}(50 \%),{ }_{45} \mathrm{M}_{5}(45 \%), \mathrm{I}_{40} \mathrm{M}_{10}(40 \%)$ dan $\mathrm{I}_{35} \mathrm{M}_{15}(35 \%)$ penambahan tepung mangrove pada stik ikan tidak berpengaruh nyata. Hasil penilaian pada atribut sensorik rasa pada stik ikan dengan penambahan tepung mangrove berpengaruh tidak nyata terhadap rerata sifat sensorik. Tingginya penambahan tepung mangrove dalam pembuatan stik ikan tuna menimbulkan rasa sepat. Rasa sepat berasal dari getah dan senyawa tannin yang terdapat dalam buah mangrove. Pengolahan buah mangrove menjadi tepung mengakibatkan rasa sepat semakin berkurang. Oleh karena itu, dengan adanya penambahan tepung mangrove rasa sepat pada stik ikan agak terasa walaupun tidak dominan. Hal ini sesuai dengan pendapat Sa'adah (2010), yang menjelaskan bahwa tepung lindur mengandung tanin, tanin sangat berpengaruh terhadap rasa dodol. Pada tumbuhan, tanin biasanya memberikan rasa sepat. Perkasa (2013), menambahkan bahwa rasa tepung lindur yang terlalu pekat akibat penambahan jumlah tepung lindur yang terlalu banyak, akan menutupi rasa dari bahanbahan lain sehingga tingkat kesukaan panelis akan menurun seiring dengan bertambahnya konsentrasi tepung lindur yang digunakan.

\section{e. Kenampakan}

Hasil penilaian pada atribut sensorik kenampakan pada stik ikan dengan penambahan tepung mangrove. Hasil analisis keragaman menunjukkan bahwa penambahan tepung mangrove pada stik ikan berpengaruh sangat nyata terhadap rerata uji sensorik 
kenampakan dan hasil uji DMRT disajikan pada Tabel 1.

Berdasarkan data Tabel 1 rarata hasil uji sensorik kenampakan stik ikan pada perlakuan $\mathrm{I}_{40} \mathrm{M}_{10}$ diperoleh nilai tertinggi yaitu 6,6. Penelitian ini menunjukkan bahwa semakin banyak konsentrasi tepung mangrove maka kenampakan yang dihasilkan akan semakin kurang menarik. Stik ikan tuna dengan tepung mangrove $10 \%$ lebih disukai dibandingkan dengan konsentrasi tepung mangrove 15\%. Hal ini dikarenakan warna yang dihasil pada konsentrasi 10\% lebih menarik (kuning kecoklatan) sedangkan pada konsentrasi 15\% kurang menarik (coklat tua). Semakin banyak jumlah tepung mangrove yang ditambahkan maka warna yang dihasilkan akan semakin gelap (coklat tua). Warna gelap (coklat tua) yang dihasilkan dikarenakan senyawa tanin yang terkandung dalam tepung mangrove. Hal ini sesuai dengan pendapat
Winarno (2004), menyatakan bahwa tanin disebut juga asam tanat atau asam galotanat, yang dapat tidak berwarna sampai berwarna kuning atau coklat. Berdasarkan uji DMRT yang dilakukan antara perlakuan $\mathrm{I}_{40} \mathrm{M}_{10}$ dengan konsentrasi $10 \%$ dan $\mathrm{I}_{35} \mathrm{M}_{15}$ dengan konsentrasi $15 \%$ tidak terdapat pengaruh yang signifikan sedangkan pada perlakuan $\mathrm{I}_{50} \mathrm{M}_{0}$ dengan $\mathrm{I}_{40} \mathrm{M}_{10}$ dan $\mathrm{I}_{45} \mathrm{M}_{5}$ sangat berpengaruh nyata.

\section{B. Analisis Kimia \\ a. Kadar Air}

Hasil penilaian uji kimia kadar air stik ikan dengan penambahan tepung mangrove. Hasil analisis keragaman menunjukkan bahwa penambahan tepung mangrove pada stik ikan berpengaruh sangat nyata terhadap rerata uji kimia stik ikan dan hasil uji (DMRT0,05) dapat dilihat pada Tabel 2.

Tabel 2. Rerata hasil penelitian uji proksimat stik ikan

\begin{tabular}{lll}
\hline Perlakuan & Rerata kadar air \pm SD & Rerata kadar protein \pm SD \\
\hline $\mathrm{I}_{50} \mathrm{M}_{0}$ & $3,24 \pm 0,52^{\mathrm{a}}$ & $10,97 \pm 0,52^{\mathrm{a}}$ \\
$\mathrm{I}_{45} \mathrm{M}_{5}$ & $5,38 \pm 0,54^{\mathrm{b}}$ & $11,98 \pm 0,54^{\mathrm{b}}$ \\
$\mathrm{I}_{40} \mathrm{M}_{10}$ & $6,45 \pm 0,55^{\mathrm{c}}$ & $13,61 \pm 0,55^{\mathrm{c}}$ \\
$\mathrm{I}_{35} \mathrm{M}_{15}$ & $9,52 \pm 0,56^{\mathrm{d}}$ & $14,58 \pm 0,56^{\mathrm{d}}$
\end{tabular}

Ket: angka yang diikiuti dengan notasi huruf yang berbeda menunjukkan nilai yang berbeda nyata pada tingkat kepercayaan 95\% $(\alpha<0,05)$

Berdasarkan hasil penelitian diperoleh nilai kadar air tertinggi terdapat pada perlakuan $\mathrm{I}_{35} \mathrm{M}_{15}$ yaitu 9,52 . Hasil penelitian menunjukkan bahwa semakin banyak jumlah tepung mangrove yang ditambahkan maka semakin tinggi pula kadar air yang dihasilkan. Rerata hasil penilaian stik ikan tuna dengan penambahan tepung mangrove diperoleh nilai rerata tertinggi terdapat pada perlakuan $\mathrm{I}_{35} \mathrm{M}_{15}$ sekitar 9,52 dengan konsentrasi tepung mangrove 15\% (Tabel 2).

Peningkatan kadar air diduga karena adanya penambahan tepung mangrove sekitar $15 \%$ sehingga membuat kadar air pada stik ikan meningkat. Penelitian ini sesuai dengan pendapat Rosiyadi (2014) yang menjelaskan bahwa semakin banyak proporsi tepung mangrove (lindur) yang ditambahkan maka akan semakin tinggi kadar air dari lempeng buah mangrove. Meningkatnya kadar air diduga disebabkan karena tepung mangrove memiliki kandungan serat yang relatif cukup tinggi, semakin tinggi kadar serat maka semakin banyak kadar air yang terikat. Serat dapat mengikat air melalui gugus hidroksil sehingga lebih banyak air yang terperangkap dalam jaringan. Rompis (1998), kadar air pada suatu produk erat hubungannya dengan pengikatan air oleh protein, yaitu pengikatan air yang tinggi akan mengurangi pelepasan air selama pemasakan, dengan demikian kadar air produk akan tinggi. Begitu pula sebaliknya, kemampuan pengikatan air yang rendah akan menyebabkan tingginya tingkat kehilangan air selama pemasakan, sehingga kadar air produk akan rendah. Kadar air pada stik ikan menurut SNI 01-2886-2000 (BSN, 2000) maksimal sebesar 4\%. Maka kadar air 
stik ikan pada I50M0 $_{5}$ yang dihasilkan telah memenuhi persyaratan standar mutu.

\section{b. Kadar Protein}

Hasil uji ANOVA (Tabel 2) menunjukkan bahwa kadar protein stik ikan yang ditambahkan dengan tepung buah mangrove menunjukkan hasil yang berbeda nyata $(a<0,05)$. Hasil uji lanjut DMRT menunjukkan nilai kadar protein stik ikan dengan penambahan tepung buah mangrove $15 \%$ berbeda nyata dengan penambahan tepung mangrove $10 \%$, $5 \%$ dan $0 \%$. Kadar protein tertinggi terdapat pada perlakuan $\mathrm{I}_{35} \mathrm{M}_{15}$ sekitar 14,58 dengan konsentrasi tepung mangrove $15 \%$.

Tepung mangrove memiliki kandungan protein yang cukup tinggi sehingga dengan adanya penambahan tepung mangrove maka kadar protein pada stik ikan akan semakin meningkat. Hal ini sesuai dengan penelitian Rhomdan (2015), hasil uji protein tepung mangrove $B$. gymnorrhiza pada nugget ikan kurusi menunjukkan bahwa substitusi tepung mangrove akan meningkatkan kadar proteinnya. Hal ini diduga karena tepung mangrove memiliki kadar protein lebih tinggi dibandingkan tepung tapioka. Sulistyawati et al., (2012), juga menyatakan bahwa protein tepung buah mangrove B. gymnorrhiza mempunyai kadar protein $5,5 \%$. Sebenarnya kadar

\section{DAFTAR PUSTAKA}

[AOAC] Association of Official Analytical Chemist. 2005. Official Methods of Analysis (18 Edn). Chap 3.003, 3.004, 43.275, 3.124. Association of Official Analytical Chemist Inc. Mayland. USA.

Ariyani, Sulistyaningrum, Tyas Wara, Norhayani. 2016. Pengaruh Penambahan Rumput Laut (Eucheuma cottonii) pada Pengolahan Fishstick Ikan Toman (Channa micropeltes). Fakultas Pertanian Universitas Palangka Raya

Bayu A. 2009. Hutan Mangrove sebagai Salah Satu Sumber Produk Alam Laut. Jurnal Oseana 34 (2) : 15-23.

BSN.2006.SNI Petunjuk Pengujian Organoleptik atau sensori (SNI 01-2346-2006).Badan Standarisasi Nasional.Jakarta. protein terjadi penurunan dari protein total pada saat perebusan, karena pada proses perebusan protein terlarut dapat terlarut dalam air perebusan. Hal ini didukung dengan pendapat Widjarnako et al.,(2012), bahwa penggunaan air secara langsung akan melarutkan sebagian protein kedalam air perebusan. Menurut Suwedja (2011) pada suhu tinggi protein akan terdegradasi. Hal ini disebabkan selama pengolahan terutama pada saat proses perebusan, paling banyak terjadi kehilangan asam amino bebas yaitu sekitar $40 \%$ dari total asam amino bebas dalam daging.

\section{KESIMPULAN}

Berdasarkan data pengamatan diatas dapat ditarik kesimpulan bahwa:

1. Berdasarkan penilaian sifat sensorik diperoleh nilai tertinggi rerata hasil atribut sensorik warna $(7,08)$, aroma $(6,07)$, tekstur $(7,03)$, kenampakan $(6,6)$, dan rasa $(6,71)$ Sedangkan pada kadar air sekitar $(9,52)$ dan kadar protein $(14,58)$.

2. Berdasarkan data sifat sensorik dapat disimpulkan bahwa terdapat pengaruh yang signifikan terhadap sifat sensorik warna, aroma, kerenyahan, kenampakan, kadar air dan kadar protein namun pada atribut sensorik rasa tidak terdapat pengaruh yang signifikan.

[Ditjen PT] Direktorat Jenderal Perikanan Tangkap (ID). 2015. Buku Statistik KKP. 1(1): 40-60

Fortuna, James de .2005. Ditemukan Buah Bakau Sebagai Makanan Pokok. http://www.tempointeraktif.com. Diakses dari internet tanggal 19 Maret 2011.

Haryono, T. 2004. Keripik buah mangrove, upaya melestarikan hutan. Kompas, Selasa 5/11/2004

Laga, A.2006.Pengembangan Pati Termodifikasi dari Substrat Tapioka dengan Optimalisasi Pemotongan Rantai Cabang Menggunakan Enzim Pullulanase.Prosing Seminar Nasional.PATPI.Yogyakarta.

Liviawaty Evi, Kurniawan Nia, Alno Muammar. 2018. Substitusi Tepung Daging Buah Lindur Terhadap Tingkat Kesukaan Bakso Ikan Lele. Program Studi Perikanan. Fakultas Perikanan 
dan IImu Kelautan. Universitas Padjadjaran. Bandung.

Perkasa, H.B. 2013. Pemanfaatan Tepung Buah Lindur (Bruguiera gymnorrhiza) dalam pembuatan biscuit.Skripsi. IPB. Bogor.

[PPS Kendari] Pelabuahan Perikanan Samudra Kendari (ID). 2016. Buku Profile (Statistik) PPS Kendari. Direktorat Jendral Kementrian Kelautan Perikanan (KKP). 1(1): 13-19

Romadhon, Nabillah Pinka Almira Dhinendra, Eko Nurcahya Dewi. 2015.Substitusi Tepung Buah Mangrove (Bruguiera Gymnorrhiza) Terhadap Sifat Fisika Dan Kimia Naget Ikan Kurisi (Nemipterusnematophorus).Jurnal Saintek Perikanan Vol.11 No.1:57-61, Agustus 2015.

Rompis JEG. 1998. Pengaruh Kombinasi Bahan Pengikat dan Bahan Pengisi terhadap Sifat Fisik, Kimia Serta Palatabilitas Sosis Sapi. Bogor: Program Pasca Sarjana, Institut Pertanian Bogor.

Rosyadi, E., SB. Widjarnako dan D.W. Ningtyas.2014. Pembuatan Lempeng Buah Lindur (Bruguiera gymnorrhiza) Dengan Penambahan Tepung Ubi Kayu (Manihot esculenta crants) Jurnal Pangan Agroindustri Vol. 2 No. 4. Hal 10-17.

Sa'adah L, Ghanaim F, Elok KM. 2010. Fraksinasi dan identifikasi senyawa tanin pada daun belimbing wuluh. Jurnal Kimia 4(2), 193-200.

Salim E. Mengolah Singkong menjadi Tepung Mocaf. 2011. Yogyakarta: Lily Publisher

[SNI] Standar Nasional Indonesia 012713.2000.Kerupuk Ikan.Dewan Standardisasi Nasional. Jakarta:Departemen Perindustrian.

Seknun, N. 2012. Pemanfaatan Tepung Buah Lindur (Bruguiera gymnorrhiza) Dalam Pembuatan Dodol Sebagai Upaya Peningkatan Nilai Tambah. [Skripsi].Program Studi Teknologi Hasil Perikanan, FPIK, IPB,Bogor.

Suwedja, I. K. 2011. Biokimia Hasil Perikanan. Media Prima Aksara. Jakarta.

Sulistyawati, Wignyanto, S. Kumalaningsih. 2012. Produksi Tepung Buah Lindur (Bruguiera gymnorrhiza) Rendah Tanin dan HCN Sebagai Bahan Pangan Alternatif. Jurnal Teknologi Pertanian, IPB, Bogor.13(13): 187 - 198.

Stanby M. 1982. Industry Fishery Technology: A Survey of Methods for Domestic Harvesting, Preservation, and Processing of Fish Used for Food and for Industrial Products. Reinhold Publishing Corp. Washington.
Wanma, A. 2007. Pemanfaatan hutan mangrove Bruguiera gymnorhiza (L) lamk" sebagai bahan penghasil karbohidrat. Konservasi Lahan Basah Vol. 15- No-2-Juli 2007.

Wardani. 2012. Fortifikasi Tepung Tulang Tuna Sebagai Sumber Kalsium Terhadap Tingkat Kesukaan Donat. Jurnal Perikanan Dan Kelautan, 3 (4): 41-50).

Widjanarko, S. B., E. Zubaidah dan A. M. Kusuma. 2012. Studi Kualitas Fisik-Kimia dan Organoleptik Sosis Ikan Lele Dumbo (Clarias gariepinus) Akibat Pengaruh Perebusan, Pengukusan dan Kombinasi dengan Pengasapan. FTP UNIBRAW. Malang.

Winarno .2004. Kimia Pangan dan Gizi. PT Gramedia Pustaka Utama. Jakarta. $253 \mathrm{hlm}$. 